\title{
Chapter 6 \\ Green Mitigation Strategy for Cultural Heritage Using Bacterial Biocides
}

\author{
Ana Teresa Caldeira
}

\begin{abstract}
The microbiota present in cultural heritage objects, made by diverse inorganic and organic materials and inserted into particular environment, represents a complex and dynamic ecosystem composed by bacteria, cyanobacteria, fungi, algae and lichens, which can induce decay by biological mechanisms. To control the microbial growth several methods are being applied such as mechanical and physical processes and chemical biocides. However, these methods have several weaknesses like be dangerous to handle, material incompatibility or produce environmental and health hazards. Therefore, the identification of effectively biodeteriogenic agents and the design of mitigation strategies directed to these agents without prejudice to historical materials, to the environment and to operators, taking into account the microbial community's dynamics, is an important challenge to control biodeterioration of cultural heritage. Bacteria, in particular Bacillus spp. are worth for the creation of new green biocides solutions because they produce a great variety of secondary metabolites including ribosomally and non-ribosomally synthesized antimicrobial peptides, known to possess antagonistic activities against many biodeteriogenic fungi and bacteria. The discovery of new safe active compounds and green nanotechnology for direct application in cultural heritage safeguard can in a close future contribute to potentiate a new generation of biocides and safe sustainable methods for cultural heritage.
\end{abstract}

Keywords Biodegradation/biodeterioration · Bacterial biocides · Cultural heritage · Green biocides $\cdot$ Sustainability

\footnotetext{
A. T. Caldeira ( $ه)$

HERCULES Laboratory, Évora University, Évora, Portugal

Chemistry Department, School of Sciences and Technology, Évora University, Évora, Portugal e-mail: atc@uevora.pt
} 


\section{Biodeterioration of Cultural Heritage Materials}

Biodeterioration of Cultural Heritage materials has been neglected for a long time since it was previously believed that detriment was mainly due to chemical and physical processes. Over the last decades, it has been recognized that the action of microorganisms is a critical factor in the deterioration of Cultural Heritage that needs to be considered (Caldeira et al. 2015). To fully understand the role of biodeterioration/biodegradation processes and the deleterious effects on cultural assets it is fundamental to characterize the microbiota and to identify the microorganisms present. Furthermore, it is a key step to define efficient preventive conservation approaches and strategies to protect monuments and artworks from microbial re/colonization (Barresi et al. 2017; Rosado et al. 2013a, 2017; Piñar and Sterflinger 2009; Salvador et al. 2016, 2017).

The characterization of microbial communities, through detection and identification of microorganisms present on cultural assets can be carried out by means of specific complementary methods and new processes and strategies are constantly being developed. In the near past, research carried out in this field relied mainly on classical culture-based methodologies which are time consuming and omit slow growing and uncultivable microorganisms that may account for more than $90 \%$ of the microflora present (Amann et al. 2001; Moter and Göbel 2020). Recently, this major drawback has been tackled by the introduction of culture-independent methods based in molecular approaches to study microorganisms which are more sensitive and require smaller amounts of samples than the former (Rosado et al. 2013a, 2014a) including Random Amplified Polymorphic DNA (RAPD), MicroSatellite Primer-Polymeric Chain Reaction (MSP-PCR), restriction fragment length polymorphism (RFLP), Denaturing Gradient Gel Electrophoresis (DGGE) (González and Saiz-Jiménez 2005), RNA-FISH (Gonzalez et al. 2014, 2017; Vieira et al. 2014, 2018) and Next Generation Sequencing (NGS) (Caldeira et al. 2015; Dias et al. 2018; Rosado et al. 2014a, 2015, 2020). Furthermore, one has to take into account that the colonization and proliferation of microorganisms (like bacteria, fungi, algae and lichens) on heritage materials are influenced by microclimatic conditions such as relative humidity, temperature and light and by the intrinsic chemical nature of the support material (Pangallo et al. 2009).

Figure 6.1 shows several examples of microbial presence in some heritage materials with obvious signs of biodegradation and aesthetic damage.

Although nowadays biodeterioration is well recognized in the overall deterioration process of cultural heritage, the specific role of the different microbial species that compose the most biodeteriogenic agents in communities is not yet well understood. Many microorganisms produce serious damage in historic materials, which are decomposed by the action of specific enzymes and organic acids (Urzì and De Leo 2007; Rosado et al. 2013a, 2014b, 2015). Fungi are especially dangerous due to the fact their hyphae can easily proliferate inside heritage materials and their spores, in a dormant state, are usually present and may germinate. Furthermore, fungi can produce carboxylic acids (e.g., oxalic, citric, malic, acetic, gluconic and 

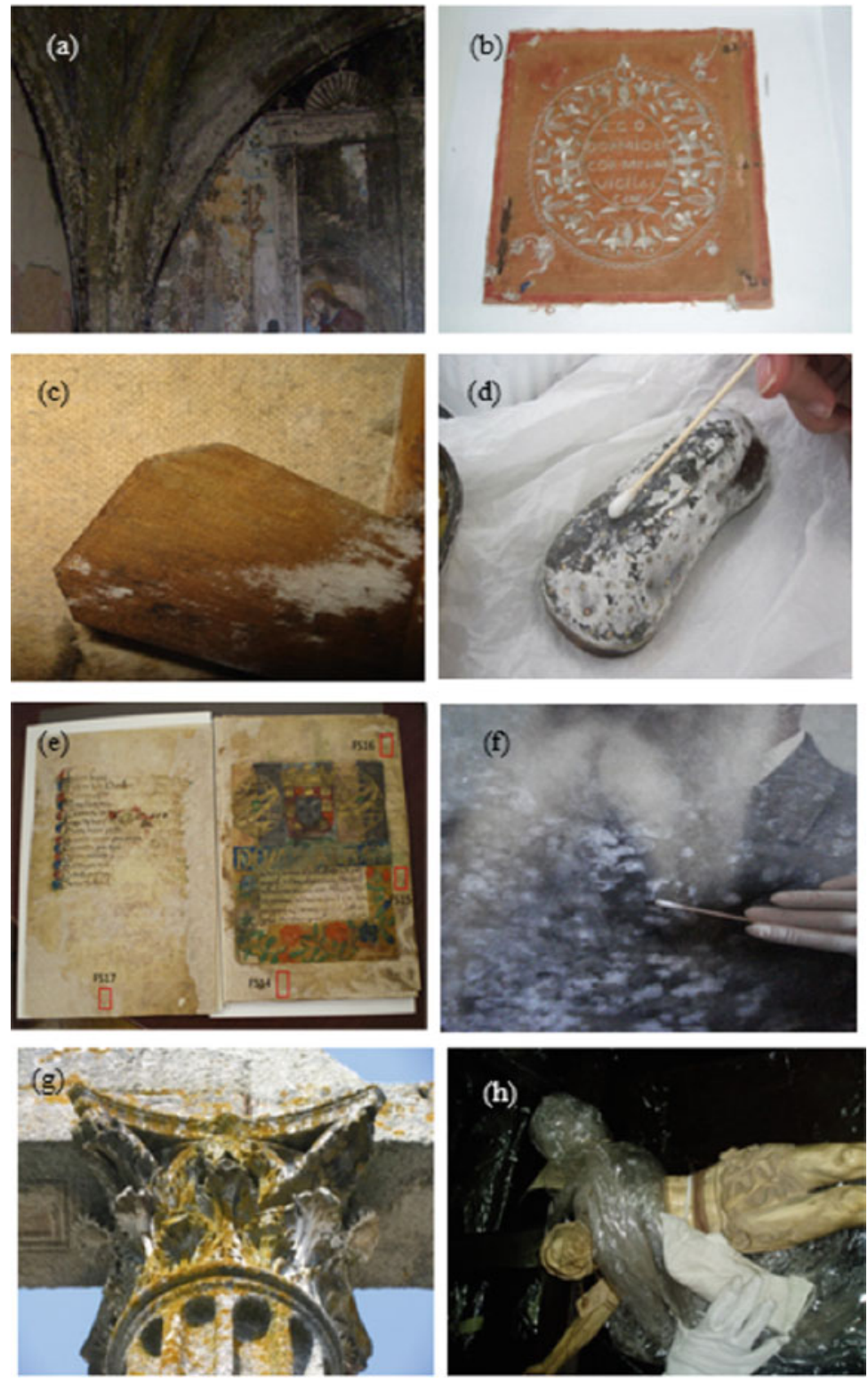

Fig. 6.1 Microbial presence in several heritage materials like (a) mortars and mural paintings, (b) textiles, (c) wood, (d) cellulose acetate, (e) parchment, (f) canvas and easel paintings, (g) marble and granite, (h) ivory, with obvious signs of biodegradation and aesthetic damage. Adapted from Caldeira et al. (2015) 
Fig. 6.2 Bacterial genera present in four easel paintings, with visible signs of degradation (a) heatmap with quantitative visualization of bacterial community composition including the 20 most abundant genus; (b) core microbiome, with taxa abundance across sample groups, including the most abundant bacterial genus

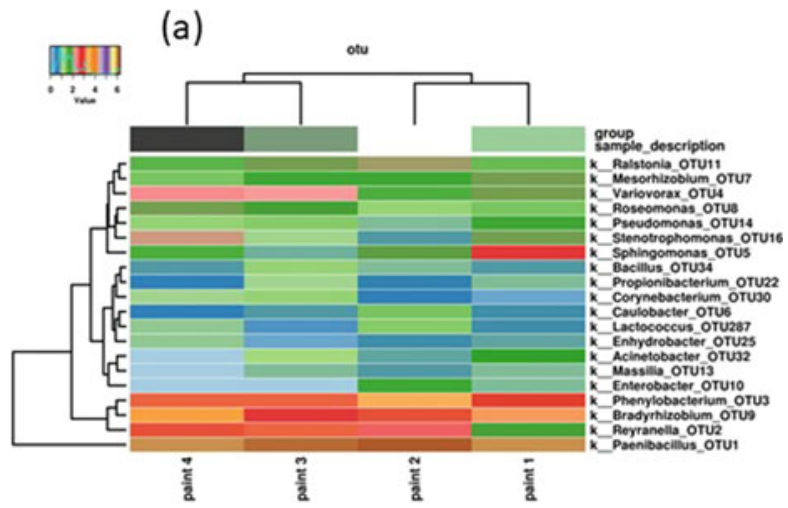

(b)

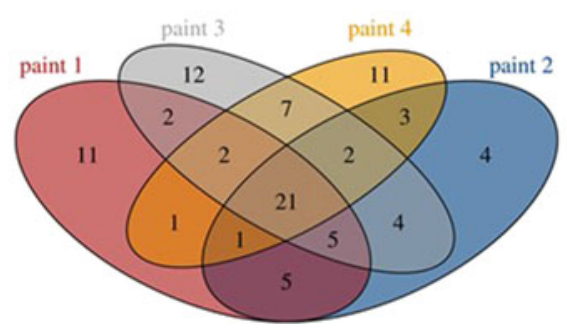

tartaric acids) which can enhance biochemical attack (Fomina et al. 2010; Hien et al. 2012; Rosado et al. 2013b, c). As reported in the literature a wide variety of fungi of the genera Alternaria, Aureobasidium, Chaetomium, Cladosporium, Curvularia, Drechslera, Fusarium, Gliomastix, Penicillium, Trichoderma, are abundant in deteriorated objects (Rosado et al. 2013a, 2014a; Sterflinger 2010). The development of fungi can induce discolouration and deterioration of surfaces, leading to the appearance of stains that alter the colour and hyphae penetration in materials may lead to detachment of fragments. Bacterial growth is frequently associated to the formation of biofilms, promoting discolouration of materials and pigments (Abdel-Haliem et al. 2013; Guiamet et al. 2011; Milanesi et al. 2006) but some metabolic compounds like oxalates and carotenes are also attributed to bacterial presence (Rosado et al. 2013a, b, 2014a, 2016) and the production of extracellular enzymes can also affect important materials, namely proteinaceous compounds in easel paintings (Salvador et al. 2019).

As an illustration, Figs. 6.1 and 6.2 show the major bacterial and fungal genera present in four easel paintings, with visible signs of degradation, all stored in the same reserve room (Fig. 6.3).

Bacterial core microbiome for the most abundant genera is composed by Bacillus, Brevundimonas, Caulobacter, Corynebacterium, Enhydrobacter, Lactococcus, Mesorhizobium, Methylobacterium, Micrococcus Paenibacillus, Phenylobacterium, 
Fig. 6.3 Fungi genera present in four easel paintings, with visible signs of degradation (a) heatmap with quantitative visualization of fungal community composition including the 20 most abundant genus and (b) core microbiome, with taxa abundance across sample groups, including the most abundant fungal genus

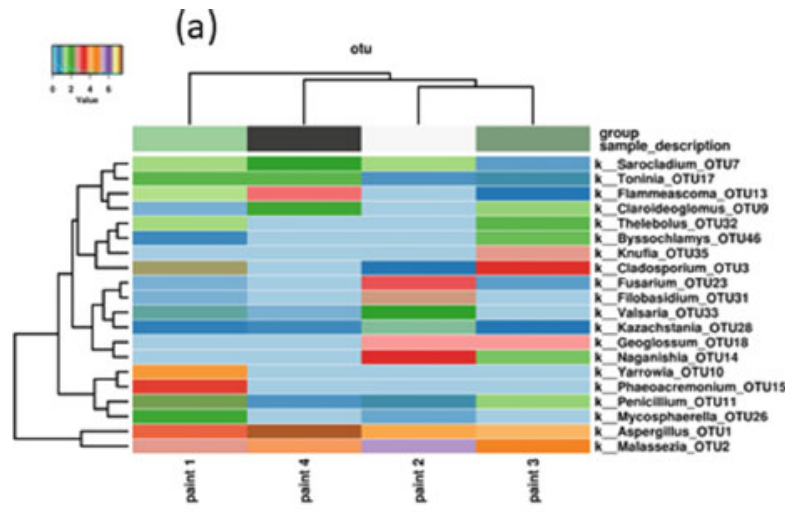

(b)

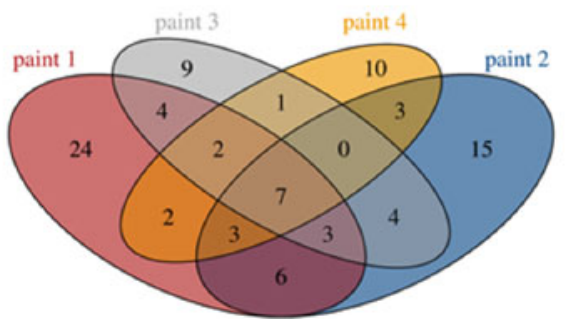

Phyllobacterium, Propionibacterium, Pseudomonas, Ralstonia, Reyranella, Roseomonas, Sphingomonas, Staphylococcus, Stenotrophomonas and Variovorax. Fungal core shows the presence of the genus Aspergillus, Cladosporium, Fusarium, Kazachstania, Malassezia, Penicillium and Zygosaccharomyces.

In fact, biodeteriogenic microorganisms cause serious aesthetical and structural damages in building materials, paintings, books or objects of inestimable value (see Fig. 6.1) which bring high expenses for museums and city councils (Allsopp 2011; Pangallo et al. 2009; Sterflinger 2010; Caldeira et al. 2018). To control the microbial growth several approaches are being applied such as mechanical and physical methods and chemical biocides (Allsopp et al. 2004; Barresi et al. 2017; FaveroLongo et al. 2017; Kakakhel et al. 2019; Pena-Poza et al. 2018; Quagliarini et al. 2018; Sanza et al. 2015).

However, these methods have several weaknesses: (i) physical methods can be dangerous to handle and promote deterioration of the object to preserve (AbdelHaliem et al. 2013; Bosch-Roig et al. 2013; Scheerer et al. 2009; Tiano 2002); (ii) mechanical methods do not completely eradicate the microorganisms and it is not possible to apply to all materials (Sanza et al. 2015); and (iii) most chemical biocides while effective produce environmental and health hazards (Allsopp et al. 2004; Young et al. 2008; Cámara et al. 2011). So, the importance of carrying out proper 
remediation action for microbiologically contaminated historic materials is of vital importance.

The identification of effectively biodeteriogenic agents and the design of mitigation strategies directed to these agents without bias to historical materials, to the environment and to operators, taking into account the perspective of the microbial communities dynamics is a major challenge to control the biodeterioration of cultural heritage and where much remains to be done.

\section{Bacterial Green Biocides for Cultural Heritage}

According to the European legislation, a biocide can be defined as "a chemical substance or microorganism intended to destroy, deter, render harmless or exert a controlling effect on any harmful organism by chemical or biological means". Unfortunately, many traditional biocides used in cultural heritage may be dangerous for human health and the environment, while they differ in their toxicological profile, as EU databases indicate (https://echa.europa.eu). The protective solutions based on the use of these toxic chemicals face increasing restrictions due to the possibility of accumulation in animal tissues (Leifert et al. 1995).

Many commercial biocides are synthetic, mainly composed by mixtures with a range of formulation additives, generally formed by quaternary ammonium compounds or other nitrogen-containing compounds, urea, benzalkonium chloride and phenol derivatives (Barresi et al. 2017; Coors et al. 2018; Favero-Longo et al. 2017; Fernandes 2006). Copper, gold, platinum, silver, titanium, zinc metal nanoparticles are also applied in the last few years (Barresi et al. 2017; Ruggiero et al. 2020).

There are also naturally occurring biocides classified as natural biocides, derived from, e.g., bacteria (Caldeira et al. 2011a; Chena et al. 2020; Colombo et al. 2019; Junier and Joseph 2017; Mariana et al. 2020; Silva et al. 2014), fungi (Hooker et al. 1994; Massart and Jijakli 2007; Suárez et al. 2007) and plants (Arantes et al. 2019a, b; Chien et al. 2019; Jeong et al. 2018; Silva et al. 2019 Jeong et al. 2018; Palla et al. 2020). A review by Fidanza and Caneva (2019) gives a description of important natural biocides for the conservation of stone in cultural heritage. Controlled release systems of biocides by encapsulation in silica were also developed for several biocides, both commercial and natural, like Biotin $\mathrm{T}$ and New Des 50 (Dresler et al. 2017), zosteric acid sodium salt, usnic acid (Ruggiero et al. 2020), among others.

In heritage context, biocides are intended to limit the microbial growth and be useful in extending the life of heritage objects but material compatibility is a critical factor to be considered. Moreover, green and non-toxic biocides are eco-friendly and promising alternatives to chemical industrial biocides that allow to avoid unnecessary costs and risks. Their production and application do not imply the implementation of a risk-management protocol for toxic compounds which is an advantage in the field of conservation and restoration. 
Therefore, it is crucial to develop green biocides compatible with historic materials that allow the elimination, inhibition and prevention of microbiological contamination.

Over the last years, some bioactive metabolites with potential applications in agriculture and pharmaceutical industries (Lowes et al. 2000; Walker et al. 1995), with a large spectrum of antimicrobial action have been reported. In agriculture the biological control of some pests has been carried out for decades through the introduction of bacteria in the soil or directly in the cultures. In recent years, interest in the biological control of phytopathogenic fungi has increased considerably because of the public concern to decrease the use of chemical pesticides and because there are some diseases that are hardly controllable by other strategies (Caldeira et al. 2011a). Besides the biocide effect, surfactins and fengycins of Bacillus subtilis prevented also the adhesion of competitive organisms on the surface of plant roots (Falardeau et al. 2013).

Mechanism and metabolite studies involved in this biological control often choose the use of bacteria (Beltran-Gracia et al. 2017), namely Bacillus spp. These microorganisms produce a variety of secondary metabolites, specifically antibiotics of peptide nature with antimicrobial properties (Caldeira et al. 2006, 2007, 2008, 2011a, b). The antimicrobial, fungicidal, insecticidal, anticarcinogenic and immunomodulating properties of lipopeptides can help to solve problems in medicine and agriculture, and the creation of an ecologically balanced environment (Maksimova et al. 2020).

A successful methodology to produce new green biocide solutions was recently developed (Silva et al. 2015, 2016a, b, 2017, 2019; Salvador et al. 2016; Rosado et al. 2019) exploring the potentialities of bioactive metabolites produced by Bacillus spp. in the cultural heritage safeguard field.

The Bacillus species are rich in biodiversity, constituting important repository bioresources, being worth for the creation of green biocides because they produce a great variety of secondary metabolites including ribosomally and non-ribosomally synthesized antimicrobial peptides, known to possess antagonistic activities against many biodeteriogenic fungi and bacteria (Berezhnayaa et al. 2019; Leifert et al. 1995; Jin et al. 2020; Medeot et al. 2020; Mikkola et al. 2004; Yazgan et al. 2001). Bacillus subtilis; B. amyloliquefaciens, B. pumilus, B. licheniformis, B. methylotrophicus, B. atrophaeus, B. laterosporus, B. paralicheniformis, B. lehensis, Paenibacillus terrae, $P$. peoriae, $P$. polymyxa, $P$. larvae, $P$. mucilaginosus, and $P$. bovis are probably the main producers of lipopeptides, which are known for their antifungal properties (Berezhnayaa et al. 2019; Caldeira et al. 2006, 2007, 2011a; Cawoy et al. 2015; Meena and Kanwar 2015; Moyne et al. 2001; Ongena and Jacques 2008; Tsuge et al. 2001; Zhao and Kuipers 2016).

Usually, three different classes of bioactive peptides can be distinguished: antimicrobial lanthipeptides ribosomally synthesized, such as subtilin, entianin, ericins, clausin, subtilomycin, thuricins, mersacidin, amylolysin, haloduracin, lichenicidin and cerecidins (Barbosa et al. 2015); and non-ribosomally synthesized antifungal peptides, such as bacilysin and rhizocticin or antifungal lipopeptides, such as surfactins, iturins and fengycins, bacillomycin, bacilysin, ericin, mersacidin, 
mycosubtilin, zwittermicins and kurstakins (Caldeira et al. 2008; Pabel et al. 2003; Rai et al. 2020).

Surfactin, iturin, bacillomycin D, fengycin and lichenysin from Bacillus species, rhamnolipids from Pseudomonas aeruginosa and daptomycin from Streptomyces roseosporus are among the most studied lipopeptides (Beltran-Gracia et al. 2017) and the gene clusters of the Bacillus lipopeptides encoding the surfactin, iturin and fengycin, families have been described and summarized in recent papers (Aleti et al. 2015; Abderrahmani et al. 2011; Deng et al. 2020; Othoum et al. 2018). These non-ribosomally synthesized compounds are amphiphilic cyclic biosurfactants that have many advantages over other biocides: low toxicity, biodegradability and environmentally friendly characteristics (Caldeira et al. 2011a). It is thought that lipopeptides act in the cell membrane of the target organism forming pores and producing an imbalance in the movement of ions both into and out, damaging the cell and producing a lethal effect. This mode of action makes it difficult for any target microorganism to gain resistance to the lipopeptide, which is a great advantage compared to other toxic compounds (Inès and Dhouha 2015; Płaza and Achal 2020; Silva et al. 2016a). These interesting properties are bringing lipopeptides to the spotlight of heritage research and testing (Caldeira et al. 2015).

The genus Bacillus includes a wide variety of species used industrially. Bacillus spp. present a great metabolic versatility, developing in almost all natural environments, the high area/volume ratio of these microorganisms allows a quick transfer of nutrients between the external environment and the interior of the cells. The resistance of spores to temperature, dehydration, radiation and other adverse environmental conditions confer a selective advantage on their survival. Some of these microorganisms can be grown in extreme temperature and $\mathrm{pH}$ conditions and produce stable products in these environments. The great physiological diversity of Bacillus spp., associated with the fact that most are not pathogenic, are easy to manipulate, good secretors of proteins and other metabolites and easily cultivable, makes them quite attractive for industrial applications (Arbige et al. 1993). Cultures of these microorganisms can be carried out in bioreactors, promoting a production of the active compounds. Some studies limiting their physiological growth by nutritional conditions, namely the carbon and nitrogen source, suggest an association between the lipopeptide production and Bacillus sporulation (Besson et al. 1987; Caldeira et al. 2008; Chevanet et al. 1986, Gonzalez-Pastor et al. 2003) evidencing higher antagonistic compounds production in cultures. Caldeira et al. (2011b, c), using an artificial intelligence approach to Bacillus amyloliquefaciens cultures, performed an Artificial Neural Network model addressing the antifungal activity of compounds produced, the Bacillus sporulation and biomass concentration obtained with different aspartic acid concentration like nitrogen source and different incubation time of cultures. This model was used to establish the operating conditions that maximize production of iturinic antimicrobial compounds. The combination of bioinformatics technology with proteomics based on mass spectrometry has shown that the synthesis of secondary metabolites from Bacillus can be regulated by quorum-sensing systems (Sandrin et al. 2013), allowing to increase the production yields. 
The control of biodegradation processes in heritage context is of utmost importance, so the high scale production of these green compounds is a promising alternative. However, only few studies (Borrego et al. 2012; Favero-Longo et al. 2017; Silva et al. 2016a; Sterflinger 2010; Urzì and De Leo 2007) have been conducted to assess the efficacy of biocides in heritage context and these are mostly on the application of industrial chemical biocides which present toxicity. To meet the public concern to reduce the use of general chemical pesticides as biocides and the professional need for more effective and safer biocides, the discovery of new bioactive molecules and the development of environmentally friendly and safe new biocides tailored by biotechnological approaches to be used in conservation prevention and treatment and as additive for new products (e.g. paints, binders and consolidants) is fundamental.

A review by Rai et al. (2020) presents a comprehensive overview of significant lipopeptides produced by plant microbiome and their role in disease control and antagonism against phytopathogens in order to evaluate their potential for future explorations as antimicrobial agents.

In the field of heritage preservation, research undertaken at HERCULES Lab has enabled the production of new biocides from liquid cultures of Bacillus amyloliquefaciens (GENBank AY785775) previously isolated from healthy Quercus suber and displaying high levels of antagonistic properties against filamentous fungi that attack forest industrial products (Caldeira et al. 2011a). These amphiphilic biosurfactants based on cyclic lipopeptides (Fig. 6.4), non-ribosomal produced by multi-enzymatic complexes, have shown a large spectrum of fungal and bacterial inhibition displaying inhibition halos greater than commercial products and lower minimal inhibitory concentrations.

Furthermore, the new biocides are harmless and handling safe, acting through a membrane breakdown mechanism of the biodeteriogen films rather than an inhibitory/toxicity mechanism. These kind of compounds, made of amino acids and a fatty acid, are easily biodegradable (Cho et al. 2003) and non-toxic (Silva et al. 2016a).

Another interesting characteristic of antagonistic lipopeptides produced by bacteria is that the same bacterial strain can synthesize several lipopeptides (see Fig. 6.4). For instance, a Bacillus sp. strain reported by Abdellaziz et al. (2018) produces surfactin, pumalicidin, lichenisin, kurstakin, and various isoforms of fengycin and many other examples can be found in the literature (Zhao and Kuipers 2016).

These types of metabolites of peptide origin synthesized non-ribosomally by multi-enzymatic complexes form a set of microbial natural products that can contain residues of unusual amino acids in proteins. These peptides can be modified, namely by glycosylations and ring formation and generate lactones or esters. The great diversity in the structure of these compounds makes them sometimes quite active, with antimicrobial properties but also as bio-tensioactive, anti-inflammatory, antiviral, cytostatic and antitumor agents (Cameotra and Makkar 2004; Carrillo et al. 2003; Davis et al. 2001; Hsieh et al. 2004; Kim et al. 1998; Kluge et al. 1988; Marahiel 1997; Ohno et al. 1992) and the culture broth often holds a synergetic effect of these mixed components. 
a)
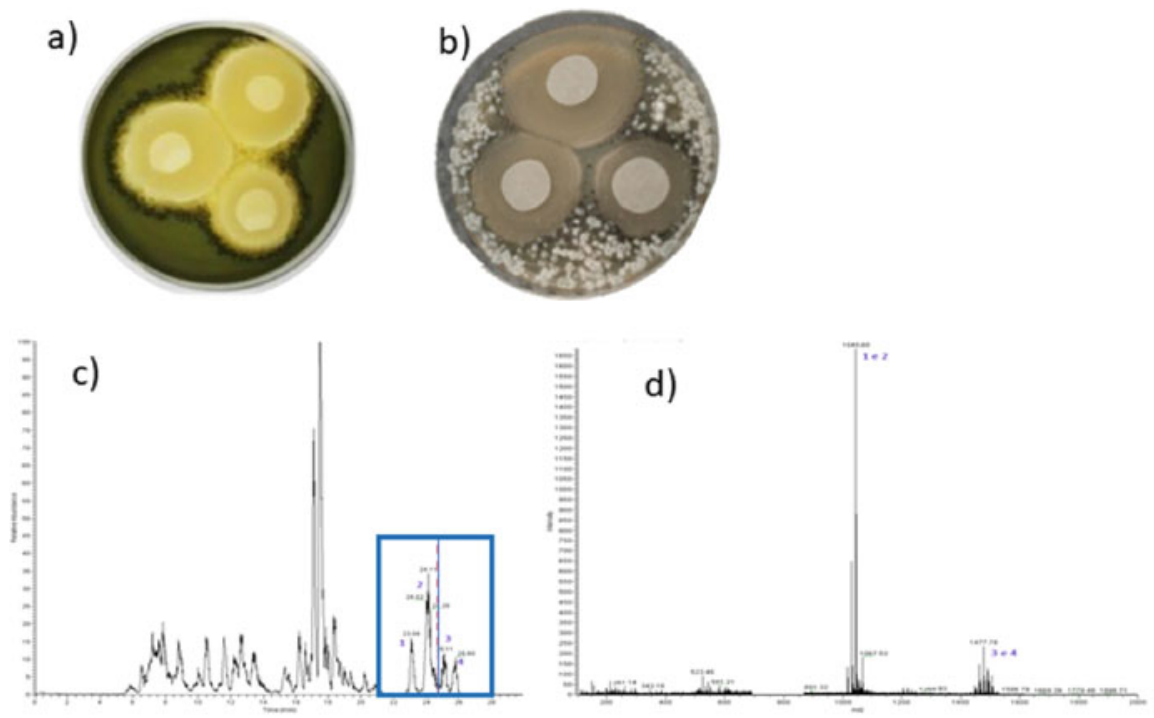

e)
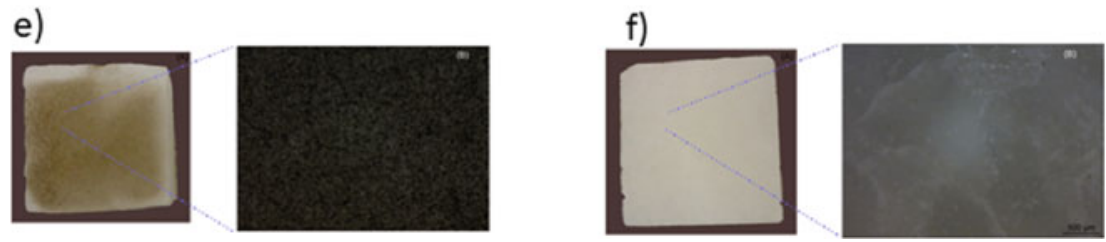

Fig. 6.4 Lipopeptide biocide inhibition against Penicillium sp. (a), and Cladosporium sp. (b). Total ion current chromatogram (TIC) of Bacillus sp. culture broth sample (c) with mass spectra of lipopeptide peaks 1-4 (d) and bioactive compounds applied in marble samples (e and f). After sterilization, marble slabs were inoculated with a mixture composed of $1 \mathrm{~mL}$ of Penicillium $10^{5} \mathrm{CFU} / \mathrm{mL}$ spore suspension, $500 \mu \mathrm{L}$ of malt extract, and $500 \mu \mathrm{L}$ of sterilized water (e) or $500 \mu \mathrm{L}$ of Bacillus sp. CCLBH 1053 liquid culture supernatant, which contained the bioactive compounds produced (f)

In the last few years, data generated by the different high-throughput technologies has expanded exponentially allowing genome sequencing of different species. Misra et al. (2019) discuss the possible development of standardized analytical pipelines that could be embraced by the omics research community highlighting recent methodologies, existing tools and potential limitations in the integration of omics datasets. The review of Mohana et al. (2018) discusses the recent progress in omicsbased applications for biodiscovery of microbial natural products in antibiotic resistance era. Recently, Kalkreuter et al. (2020) presented different examples of successful strategies based on the combination of genome sequencing and bioinformatics that have been used for natural product discovery from cultivatable bacteria and discussed the opportunities and challenges that come from the association of genome conversion into natural products. 
In fact, multi-omics methods enable us to study the potential of Bacillus antimicrobial compounds at both their compositional and functional levels.

Further insight into the potential metabolic processes, biosynthetic capabilities and stress adaptations can be inferred from genomic-scale comparison of strains. With this in mind, it is possible to screen and select strains with higher industrial potential capable to produce new desired active compounds or improve their production. Genomic approaches capable to identify the gene clusters that are localized in the genome can shed new light in the evaluation of the latent production capabilities of specific selected strains. The study of Yang Lu et al. (2019) provides a genomic and growth proteomic analysis of bacillomycin Lb biosynthesis during the $B$. amyloliquefaciens X030 growth cycle, making available a database about biosynthesis gene clusters, key regulatory enzymes, and proteins. The full-genome sequencing of a few genomes of bacteria, in particular, of the genus Bacillus, nowadays available in international databases like NCBI, allows determining the location of genetic clusters responsible for peptide synthesis. These biosynthetic gene clusters include non-ribosomal peptide synthetases (NRPSs), polyketide synthases (PKSs), and ribosomally synthesized and post-translationally modified peptides (RiPPs).

The complete genome sequence of Bacillus strains and a comparative analysis between the genome sequences revealed differences in the lipopeptide synthesis genes paving the way for the design of new solutions combining the potential of various strains of Bacillus.

Actually, we explore hypogenic environments, a robust microbial cell factory, with unexplored biosynthetic potential of strains, by omics-based approaches, to improve the antagonistic compounds (data not shown). New active compounds and green nanotechnology for direct application in cultural heritage safeguard can in a close future contribute to potentiate a future generation of biocides and safe sustainable methods.

Microorganisms are responsible for the biodeterioration of cultural heritage but can also be an important source of solutions. It's up to figure out the way....

Acknowledgements Project SCREAM: Touchstone for Heritage Endangered by Salt Crystallization - a Research Enterprise on the Art of Munch (ALT20-03-0145-FEDER-031577); project 0483_PROBIOMA_5_E, Prospecion en ambientes subterraneos de compuestos bioactivos microbianos con uso potencial para la medicina, agricultura y medio ambiente. Co-financed by the European Regional Development; and the City University of Macau endowment to the Sustainable Heritage Chair.

Ethical Statement Conflict of Interest: Authors declare that they have no conflict of interest in this study.

Ethical Approval: This article does not contain any studies with human participants or animals. 


\section{References}

Abdel-Haliem ME, Sakr AA, Ali MF, Ghaly MF, Sohlenkamp C (2013) Characterization of Streptomyces isolates causing colour changes of mural paintings in ancient Egyptian tombs. Microbiol Res 168:428-437

Abdellaziz L, Chollet M, Abderrahmani A, Bechet M, Yaici L, Chataigne G, Arias A, Leclere V, Jacques P (2018) Lipopeptide biodiversity in antifungal Bacillus strains isolated from Algeria. Arch Microbiol 200:1205-1216

Abderrahmani A, Tapi A, Nateche F, Chollet M, Leclere V, Wathelet B, Hacene H, Jacques P (2011) Bioinformatics and molecular approaches to detect NRPS genes involved in the biosynthesis of kurstakin from Bacillus thuringiensis. Appl Microbiol Biotechnol 92:571-581

Aleti G, Sessitsch A, Brader G (2015) Genome mining: prediction of lipopeptides and polyketides from Bacillus and related Firmicutes. Comput Struct Biotechnol J 13:192-203

Allsopp D (2011) Worldwide wastage: the economics of biodeterioration. Microbiol Today 38:150-153

Allsopp D, Swal K, Gaylande C (2004) The control of biodeterioration. In: Introduction to biodeterioration. Cambridge University Press, Cambridge, pp 203-223

Amann R, Fuchs B, Behrens S (2001) The identification of microorganisms by fluorescence in situ hybridisation. Curr Opin Biotechnol 12:231-236

Arantes S, Caldeira AT, Candeias A, Martins MR (2019a) Antimicrobial potential of Lamiaceae essential oils against heritage biodeteriogenic strains. Congress of Microbiology and Biotechnology, Book of abstracts Microbiotec' 19:97, Coimbra, Portugal (http://microbiotec19.net/test/ wpcontent/uploads/2019/07/Book_abstract_online.pdf)

Arantes S, Guerreiro M, Piçarra A, Caldeira AT, Martins RM (2019b). Antimicrobial potential of essential oils of Portuguese autochthonous Lavandula against resistant bacteria. Congress of Microbiology and Biotechnology, Book of abstracts Microbiotec'19, pp 313, Coimbra, Portugal (http://microbiotec19.net/test/wp-content/uploads/2019/07/Book_abstract_online.pdf)

Arbige MV, Bulthuis BA, Schultz J, Crabb D (1993) Fermentation of Bacillus. In: Sonenshein AL, Hoch JA, Losick R (eds) Bacillussubtilis and other gram-positive bacteria: biochemistry, physiology, and molecular genetics. American Society for Microbiology, Washington, DC, pp 871-895

Barbosa J, Caetano T, Mendo S (2015) Class I and class II lanthipeptides produced by Bacillus spp. J Nat Prod 78:2850-2866

Barresi G, Cammarata M, Palla F (2017) Biocide. In: Palla F, Barresi G (eds) Biotechnology and conservation of cultural heritage. Springer, Switzerland, pp 49-66

Beltran-Gracia E, Macedo-Raygoza G, Villafaña-Rojas J, Martinez-Rodriguez A, ChavezCastrillon Y, Espinosa-Escalante F, Di Mascio P, Ogura T, Beltran-Garcia M (2017) Production of lipopeptides by fermentation processes: Endophytic bacteria, fermentation strategies and easy methods for bacterial Selection. In: Angela Faustino J (ed) Fermentation Processes, IntechOpen, London. https://doi.org/10.5772/64236

Berezhnayaa A, Evdokimovaa O, Valentovicha L, Sverchkovaa N, Titoka M, Kolomiyets E (2019) Molecular genetic and functional analysis of the genome of bacteria Bacillus velezensis BIM B-439D. Appl Biochem Microbiol 55:386-396

Besson F, Chevanet C, Michel G (1987) Influence of the culture medium on the production of iturin A by Bacillus subtilis. J Gen Microbiol 3:767-772

Borrego S, Valdés O, Vivar I, Lavin P, Guiamet P, Battistoni P, Gómez de Saravia S, Borges P (2012) Essential oils of plants as biocides against microorganisms isolated from cuban and argentine documentary heritage. Int Sch Res Notices 2012:7., Article ID 826786. https://doi.org/ 10.5402/2012/826786

Bosch-Roig P, Regidor-Ros JL, Montes-Estelles R (2013) Biocleaning of nitrate alterations on wall paintings by Pseudomonas stutzeri. Int Biodeter Biodegr 84:266-274 
Britta K, Joachim V, Johann S, Klaus E (1988) Studies on the biosynthesis of surfactin, a lipopeptide antibiotic from Bacillus subtilis ATCC 21332. FEBS Lett:231. https://doi.org/10. 1016/0014-5793(88)80712-9

Caldeira AT, Savluchinske-Feio S, Arteiro JM, Roseiro J (2006) Antimicrobial activity of steadystate cultures of Bacillus sp. CCMI 1051 against wood contaminant fungi. Biochem Eng J 30:231-236

Caldeira AT, Savluchinske-Feio S, Arteiro JM, Roseiro J (2007) Bacillus amyloliquefaciens CCMI 1051 in vitro activity against wood contaminant fungi. Ann Microbiol 57:29-34

Caldeira AT, Savluchinske-Feio S, Arteiro JM, Coelho A, Roseiro J (2008) Environmental dynamics of Bacillus amyloliquefaciens CCMI1051 antifungal activity under different nitrogen patterns. J Appl Microbiol 104:808-816

Caldeira AT, Arteiro JM, Coelho A, Roseiro J (2011a) Combined use of LC-ESI-MS and antifungal tests for rapid identification of bioactive lipopeptides produced by Bacillus amyloliquefaciens CCMI 1051. Process Biochem 46(9):1738-1746

Caldeira AT, Vicente H, Arteiro JM, Roseiro J, Neves J (2011b) An artificial intelligence approach to Bacillus amyloliquefaciens CCMI 1051 cultures: application to the production of antifungal compounds. Bioresour Technol 102:1496-1502

Caldeira AT, Vicente H, Arteiro JM, Roseiro J, Neves J (2011c) Production of bioactive compounds against wood contaminant fungi: an artificial intelligence approach. In: Caldeira $F$ (ed) Minimizing the environmental impact of the forest products industries. UFP Editions, Porto, pp 131-137

Caldeira AT, Rosado T, Silva M, Gonzalez M, Candeias A (2015) Microrganismos e Património Novas abordagens. Magazine da Sociedade Portuguesa de Microbiologia 4:1-7

Caldeira AT, Salvador C, Rosado T, Teixeira D (2018) Biodeterioration of easel paintings - an overview. In: Mitchell R, Clifford J (eds) Biodeterioration and preservation in art, archaeology and architecture. Archetype Publications, London, pp 71-78

Cámara B, De los Ríos A, Urizal M, Buergo M, Varas MJ, Fort R, Ascaso C (2011) Characterizing the microbial colonization of a dolostone quarry: implications for stone biodeterioration and response to biocide treatments. Microb Ecol 62:299-313

Cameotra SS, Makkar RS (2004) Recent applications of biosurfactants as biological and immunological molecules. Curr Opin Microbiol 7:262-266

Carrillo PM, Robinson HS, Anumba CJ, Al-Ghassani AM (2003) IMPaKT: a framework for linking knowledge management to business performance. Electron J Knowl Manag 1(1):1-12

Cawoy H, Debois D, Franzil L, De Pauw E, Thonart P, Ongena M (2015) Lipopeptides as main ingredients for inhibition of fungal phytopathogens by Bacillus subtilis/amyloliquefaciens. Microb Biotechnol 8:281-295

Chena J, Xue Q, Mac CL, Tan X (2020) Streptomyces pactum may control Phelipanche aegyptiaca in tomato. Appl Soil Ecol 146:103369

Chevanet C, Besson F, Michel G (1986) Effect of various growth conditions on spore formation and bacillomycin L production in Bacillus subtilis. Can J Microbiol 32:254-258

Chien H, Kuo C, Kao L, Lin G, Chen P (2019) Polysaccharidic spent coffee grounds for silver nanoparticle immobilization as a green and highly efficient biocide. Int $\mathrm{J}$ Biol Macromol 140:168-176

Cho SJ, Lee SK, Cha BJ, Kim YH, Shin KS (2003) Detection and characterization of the Gloeosporium gloeosporioides growth inhibitory compound iturin A from Bacillus subtilis strain KS03. FEMS Microbiol Lett 223:47-51

Colombo EM, Kunova A, Pizzatti C, Saracchi M, Cortesi P, Pasquali M (2019) Selection of an endophytic streptomyces sp. strain DEF09 from wheat roots as a biocontrol agent against Fusarium graminearum. Front Microbiol 10:1-12

Coors A, Vollmar P, Heim J, Sacher F, Kehrer A (2018) Environmental risk assessment of biocidal products: identification of relevant components and reliability of a component based mixture assessment. Environ Sci Eur 30(3):1-15 
Davis DA, Lynch HC, Varley J (2001) The application of foaming for the recovery of Surfactin from B. subtilis ATCC 21332 cultures. Enzym Microb Technol 28:346-354. https://doi.org/10. 1016/S0141-0229(00)00327-6

Deng Q, Wang R, Sun D, Sun L, Wang Y, Pu Y, Fang Z, Xu D, Liu Y, Ye R, Yin S, Xie S, Gooneratne R (2020) Complete genome of Bacillus velezensis CMT-6 and comparative genome analysis reveals lipopeptide diversity. Biochem Genet 58:1-15

Dias L, Rosado T, Coelho A, Barrulas P, Lopes L, Moita P, Candeias A, Mirão J, Caldeira AT (2018) Natural limestone discolouration triggered by microbial activity-a contribution. AIMS Microbiol 4:594-607

Dresler C, Saladino M, Demirbag C, Caponetti E, Martino D, Alduina R (2017) Development of controlled release systems of biocides for the conservation of cultural heritage. Int Biodeterior Biodegrad 125:150-156

Falardeau J, Wise C, Novitsky L, Avis TJ (2013) Ecological and mechanistic insights into the direct and indirect antimicrobial properties of Bacillus subtilis Lipopeptides on plant pathogens. $\mathrm{J}$ Chem Ecol 39(7):869-878

Favero-Longo S, Benesperi R, Bertuzzi S, Bianchi E, Buffa G, Giordani P, Loppi S, Malaspina P, Matteucci E, Paoli L, Ravera S, Roccardi A, Segimiro A, Vannini A (2017) Species- and sitespecific efficacy of commercial biocides and application solvents against lichens. Int Biodeterior Biodegrad 123:127-137

Fernandes P (2006) Applied microbiology and biotechnology in the conservation of cultural heritage materials. Appl Microbiol Biotechnol 73:291-296

Fidanza M, Caneva G (2019) Natural biocides for the conservation of stone cultural heritage: a review. J Cult Herit 38:271-286

Fomina M, Burford P, Hillier S, Kierans M, Gadd M (2010) Rock-building fungi. Geomicrobiol J 27:624-629

González JM, Saiz-Jiménez C (2005) Application of molecular nucleic acid-based techniques for the study of microbial communities in monuments and artworks. Int Microbiol 8:189-194

Gonzalez M, Vieira R, Nunes P, Rosado T, Martins S, Candeias A, Pereira A, Caldeira AT (2014) Fluorescence In Situ hybridization: a potentially useful technique for detection of microorganisms on mortars. e-conser J 2:44-52

Gonzalez M, Brinco C, Vieira R, Rosado T, Mauran G, Pereira A, Candeias A, Caldeira AT (2017) Dual phylogenetic staining protocol for simultaneous analysis of yeast and bacteria in artworks. Appl Phys A:123-142

Gonzalez-Pastor J, Hobbs E, Losick R (2003) Cannibalism by sporulating bacteria. Science 301:510-513

Guiamet P, Borrego S, Lavin P, Perdomo I, Saravia SGD (2011) Biofouling and biodeterioration in materials stored at the historical archive of the Museum of La Plata, Argentine and at the National Archive of the Republic of Cuba. Colloids Surf B Biointerf 85:229-234

Hien TH, Govin A, Guyonnet R, Grosseau P, Lors C, Garcia-Diaz E, Damidot D, Devès O, Ruot B (2012) Influence of the intrinsic characteristics of mortars on biofouling by Klebsormidium flaccidum. Int Biodeterior Biodegrad 70:31-39

Hooker JE, Jaizme-Vega M, Atkinson D (1994) Biocontrol of plant pathogens using arbuscular mycorrhizal fungi. In: Gianinazzi S, Schüepp H (eds) Impact of Arbuscular Mycorrhizas on sustainable agriculture and natural ecosystems. ALS Advances in Life Sciences. Birkhäuser, Basel, pp 191-200

Hsieh FC, Li MC, Lin TC, Kao SS (2004) Rapid detection and characterization of surfactinproducing Bacillus subtilis and closely related species based on PCR. Curr Microbiol 49:186191. https://doi.org/10.1007/s00284-004-4314-7

Inès M, Dhouha G (2015) Lipopeptide surfactants: production, recovery and pore forming capacity. Peptides 71:100-112

Jeong S, Lee H, Kim DW, Chung Y (2018) New biocide for eco-friendly biofilm removal on outdoor stone monuments. Int Biodeterior Biodegrad 131:19-28 
Jin P, Wang H, Tan Z, Xuan Z, Dahar GY, Li QX, Miao W, Liu W (2020) Antifungal mechanism of bacillomycin D from Bacillus velezensis $\mathrm{HN}-2$ against Colletotrichum gloeosporioides Penz. Pestic Biochem Phys 163:102-107

Junier P, Joseph E (2017) Microbial biotechnology approaches to mitigating the deterioration of construction and heritage materials. Microb Biotechnol 10(5):1145-1148

Kakakhel I, Wu F, Gu JD, Feng H, Shah K, Wang W (2019) Controlling biodeterioration of cultural heritage objects with biocides: a review. Int Biodeterior Biodegrad 143(104721):1-10

Kalkreuter E, Pan G, Cepeda A, Shen B (2020) Targeting bacterial genomes for natural product. Discovery Trends Pharmacol Sci 41:13-26

Kim K, Jung SY, Lee DK, Jung JK, Park JK, Kim DK, Lee CH (1998) Suppression of inflammatory responses by surfactin, a selective inhibitor of platelet cytosolic phospholipase $\mathrm{A}(2)$. Biochem Pharmacol 55(7):975-985. https://doi.org/10.1016/S0006-2952(97)00613-8

Leifert C, Li H, Chidburee S, Hampson S, Workman S, Sigee D, Epton H, Harbour A (1995) Antibiotic production and biocontrol activity by Bacillus subtilis CL27 and Bacillus pumilus CL45. J Appl Bacteriol 78:97-108

Lowes KF, Shearman CA, Payne J, MacKenzie D, Archer DB, Merry RJ, Gasson MJ (2000) Prevention of yeast spoilage in feed and food by the yeast mycocin HMK. Appl Environ Microbiol 66(3):1066-1076. https://doi.org/10.1128/aem.66.3.1066-1076.2000

Lu JY, Zhou K, Huang WT, Zhou P, Yang S, Zhao X, Xie J, Xia L, Ding X (2019) A comprehensive genomic and growth proteomic analysis of antitumor lipopeptide bacillomycin Lb biosynthesis in Bacillus amyloliquefaciens X030. Appl Microbiol Biotechnol 103:7647-7662

Maksimova I, Singhb B, Cherepanovaa E, Burkhanovaa G, Khairullin R (2020) Prospects and applications of lipopeptide-producing bacteria for plant protection. Appl Biochem Microbiol 56 (1): $15-28$

Marahiel MA, Stachelhaus T, Mootz HD (1997) Modular peptide synthetases involved in nonribosomal peptide synthesis. Chem Rev 97:2651-2673

Mariana M, Ohnob T, Suzukic H, Kitamurac H, Kurodac K, Shimizua M (2020) A novel strain of endophytic Streptomyces for the biocontrol of strawberry anthracnose caused by Glomerella cingulate. Microbiol Res 234(126428):1-9

Massart S, Jijakli H (2007) Use of molecular techniques to elucidate the mechanisms of action of fungal biocontrol agents: a review. J Microbiol Methods 69(2):229-241

Medeot D, Fernandez M, Morales G, Jofré E (2020) Fengycins from Bacillus amyloliquefaciens MEP218 exhibit antibacterial activity by producing alterations on the cell surface of the pathogens Xanthomonas axonopodis pv. vesicatoria and Pseudomonas aeruginosa PA01. Front Microbiol 10(3107):1-12

Meena KR, Kanwar SS (2015) Lipopeptides as the antifungal and antibacterial agents: applications in food safety and therapeutics. Biomed Res Int 2015:473050

Mikkola R, Andersson M, Grigoriev P, Teplova V, Saris N, Rainey F, Salonen M (2004) Bacillus amyloliquefaciens strains isolated from moisture-damaged buildings produced surfactin and a substance toxic to mammalian cells. Arch Microbiol 181:314-323

Milanesi C, Baldi F, Borin S, Vignani R, Ciampolini F, Faleri C, Cresti M (2006) Biodeterioration of a fresco by biofilm forming bacteria. Int Biodeterior Biodegrad 57:168-173

Misra B, Langefeld C, Olivier M, Cox L (2019) Integrated omics: tools, advances and future approaches. J Mol Endocrinol 62:21-45

Mohana N, Rao H, Rakshith D, Mithun PR, Nuthan BR, Satish S (2018) Omics based approach for biodiscovery of microbial natural products in antibiotic resistance era. J Genet Eng Biotechnol 16(1):1-8

Moter A, Göbel U (2020) Fluorescence in situ hybridization (FISH) for direct visualization of microorganisms. J Microbiol Methods 41(2):85-112

Moyne A, Shelby R, Cleveland T, Tuzun S (2001) Bacillomycin D: an iturin with antifungal activity against Aspergillus flavus. J Appl Microbiol 90:622-629

Ongena M, Jacques P (2008) Bacillus lipopeptides: versatile weapons for plant disease biocontrol. Trends Microbiol 16:115-125 
Ohno A, Takashi A, Shoda M (1992) Production of a lipopeptideantibiotic surfactin with recombinant Bacillus subtilis. Biotechnol Lett 14:1165-1168

Othoum G, Bougouffa S, Razali R et al (2018) In silico exploration of Red Sea Bacillus genomes for natural product biosynthetic gene clusters. BMC Genomics 19:382. https://doi.org/10.1186/ s12864-018-4796-5

Pabel C, Vater J, Wilde C, Franke P, Hofemeisrer J, Adler B, Bringmann G, Hacker J, Hentschel U (2003) Antimicrobial activities and matrix-assisted laser desorption/ionization mass spectrometry of Bacillus isolates from the marine sponge Aplysina aerophoba. Mar Biotechnol 5:424-434

Palla F, Bruno M, Mercurio F, Tantillo A, Rotolo V (2020) Essential oils as natural biocides in conservation of cultural heritage. Molecules 25(730):1-11

Pangallo D, Chovanová K, Simonovicova A, Ferianc P (2009) Investigation of microbial community isolated from indoor artworks and air environment: identification, biodegradative abilities, and DNA typing. Can J Microbiol 55:277-287

Pena-Poza J, Ascaso C, Sanz M, Pérez-Ortega S, Oujja M, Wierzchos J, Souza-Egipsy V, Cañamares MV, Urizal M, Castillejo M, García-Heras M (2018) Effect of biological colonization on ceramic roofing tiles by lichens and a combined laser and biocide procedure for its removal. Int Biodeterior Biodegrad 126:86-94

Piñar G, Sterflinger K (2009) Microbes and building materials. In: Cornejo DN, Haro JL (eds) Building materials: properties, performance and applications. Nova Science Publishers, New York, pp 163-188

Płaza G, Achal V (2020) Biosurfactants: eco-friendly and innovative biocidesagainst biocorrosion. Int J Mol Sci 21:2152

Quagliarini E, Graziani L, Diso D, Licciulli A, D’Orazio M (2018) Is nano-TiO2 alone an effective strategy for the maintenance of stones in cultural heritage? J Cult Heritage 30:81-91

Rai J, Singh H, Brahmaprakash G (2020) Lesson from ecotoxicity: revisiting the microbial lipopeptides for the management of emerging diseases for crop protection. Int J Environ Res Public Health 17(1434):1-27

Rosado T, Martins MR, Pires M, Mirão J, Candeias A, Caldeira AT (2013a) Enzymatic monitorization of mural paintings biodeterioration. Int J Cons Sci 4:603-612

Rosado T, Gil M, Mirão J, Candeias A, Caldeira AT (2013b) Oxalate biofilm formation in mural paintings due to microorganisms - a comprehensive study. Int Biodeterior Biodegrad 85:1-7

Rosado T, Mirão J, Gil M, Candeias A, Caldeira AT (2013c) Evaluation of mural paintings biodeterioration by oxalate formation. In: Rogerio-Candelera MA, Lazzari M, Cano E (eds) Science and technology for the conservation of cultural heritage. CRC Press/Balkema, London, pp 147-150

Rosado T, Mirão J, Candeias A, Caldeira AT (2014a) Microbial communities analysis assessed by pyrosequencing - a new approach applied to conservation state studies of mural paintings. Anal Bioanal Chem 406:887-895

Rosado T, Reis A, Mirão J, Candeias A, Vandenabeeled P, Caldeira AT (2014b) Pink! Why not? On the unusual colour of Évora Cathedral. Int Biodeterior Biodegrad 94:121-127

Rosado T, Mirão J, Candeias A, Caldeira AT (2015) Characterizing microbial diversity and damage in mural paintings. Microsc Microanal 21(1):78-83

Rosado T, Gil M, Mirão J, Candeias A, Caldeira AT (2016) Darkening on lead based pigments: microbiological contribution. Color Res Appl 41(3):294-298

Rosado T, Silva M, Dias L, Candeias A, Gil M, Mirão J, Pestana J, Caldeira AT (2017) Microorganisms and the integrated conservation-intervention process of the renaissance mural paintings from Casas Pintadas in Évora - know to act, act to preserve. J King Sau Univ - Sci 29 (4):478-486

Rosado T, Santos R, Silva M, Galvão A, Mirão J, Candeias A, Caldeira AT (2019) Mitigation approach to avoid fungal colonisation of porous limestone. Int J conser sci 10(1):3-14

Rosado T, Dias L, Lança M, Nogueira C, Santos R, Martins MR, Candeias A, Mirão J, Caldeira AT (2020) Assessment of microbiota present on a Portuguese historical stone convent using high 
throughput sequencing approaches. Microbiol Open e1030:1-18. https://doi.org/10.1002/mbo3. 1030

Ruggiero L, Bartoli F, Fidanza MR, Zurlo F, Marconi E, Gasperi T, Tuti S, Crociani L, Di Bartolomeo E, Caneva G, Ricci MA, Sodo A (2020) Encapsulation of environmentally-friendly biocides in silica nanosystems for multifunctional coatings. Appl Surf Sci 514(145908):1-9

Salvador C, Silva M, Rosado T, Vaz Freire R, Bordalo R, Candeias A, Caldeira AT (2016) Biodeterioration of easel paintings: development of new mitigation strategies. Conservar Património 23:119-124

Salvador C, Borlado R, Silva M, Rosado T, Candeias A, Caldeira AT (2017) On the conservation of easel paintings - evaluation of microbial contamination and artist materials. Appl Phys A 123 (80): $1-13$

Salvador C, Medeiros R, Candeias A, Caldeira AT (2019) Biodeterioration of easel paintings: a case study of Munch's paintings. In: Congress of microbiology and biotechnology, book of abstracts Microbiotec'19. Portugal, Coimbra, p 90. http://microbiotec19.net/test/wp-content/uploads/ 2019/07/Book_abstract_online.pdf

Sandrin TR, Goldstein GE, Schumaker S (2013) MALDI TOF MS profiling of bacteria at the strain level: a review. Mass Spectrom Rev 32:188-217

Sanza M, Oujja M, Ascaso C, Ríos A, Pérez-Ortega S, Souza-Egipsy V, Wierzchos J, Speranza M, Canamares M, Castillejo M (2015) Infrared and ultraviolet laser removal of crustose lichens on dolomite heritage stone. Appl Surf Sci 346:248-255

Scheerer S, Ortega-Morales O, Gaylarde C (2009) Microbial deterioration of stone monuments - an updated overview. Adv Appl Microbiol 66:97-139

Silva M, Teixeira D, Silva S, Candeias A, Caldeira AT (2014) Production of novel biocides for cultural heritage from Bacillus sp. In: Rogerio-Candelera MA (ed) Science, technology and cultural heritage. CRC Press/Balkema, London, pp 223-228

Silva M, Rosado T, Teixeira D, Candeias A, Caldeira AT (2015) Production of Green biocides for cultural heritage- novel biotechnological solutions. Int J Conerv Sci 6:519-530

Silva M, Vador C, Candeias MF, Teixeira D, Candeias A, Caldeira AT (2016a) Toxicological assessment of novel green biocides for cultural heritage. Int J Conserv Sci 7:265-272

Silva M, Pereira A, Teixeira D, Candeias A, Caldeira AT (2016b) Combined use of NMR, LC-ESIMS and antifungal tests for rapid detection of bioactive lipopeptides produced by Bacillus. Adv Microbiol 6:788-796

Silva M, Rosado T, Teixeira D, Candeias A, Caldeira AT (2017) Green mitigation strategy for cultural heritage: bacterial potential for biocide production. Environ Sci Pollut Res 24:4871-4881

Silva M, Rosado T, Lopes da Silva Z, Nóbrega Y, Silveira D, Candeias A, Caldeira AT (2019) Green bioactive compounds: mitigation strategies for cultural heritage. Conserv Sci Culture Heritage 19:133-142

Sterflinger K (2010) Fungi: their role in deterioration of cultural heritage. Fungal Biol Rev 24:47-55

Suárez MB, Vizcaíno JA, Llobell A, Monte E (2007) Characterization of genes encoding novel peptidases in the biocontrol fungus Trichoderma harzianum CECT 2413 using the Tricho EST functional genomics approach. Curr Genet 51:331-342

Tiano P (2002) Biodegradation of cultural heritage: decay, mechanisms and control methods. Seminar article, New University of Lisbon, Department of Conservation and Restoration, 7-12 (http://www.arcchip.cz/w09/w09_tiano.pdf)

Tsuge K, Akiyama T, Shoda M (2001) Isolation of a gene essential for biosynthesis of the lipopeptide antibiotics plipastatin B1 and surfactin in Bacillus subtilis YB8. J Bacteriol 183:6265-6273

Urzì C, De Leo F (2007) Evaluation of the efficiency of water-repellent and biocide compounds against microbial colonization of mortars. Int Biodeterior Biodegrad 60:25-34

Vieira R, Nunes P, Martins S, González M, Rosado T, Pereira A, Candeias A, Caldeira AT (2014) Fluorescence in situ hybridisation for microbiological detection in mortars. In: Rogerio- 
Candelera (ed) Science, technology and cultural heritage. CRC Press/Balkema Taylor \& Francis Group, London, pp 257-262

Vieira R, Pazian M, González-Pérez M, Pereira A, Candeias A, Caldeira AT (2018) Detecting cells with low RNA content colonizing artworks non-invasively: RNA-FISH. In: Mosquera MJ, Gil A (eds) Conserving cultural heritage. CRC Press/Balkema, London, pp 303-305

Walker GM, Mcleod AH, Hodgson VJ (1995) Interactions between killer yeasts and pathogenic fungi. FEMS Microbiol Lett 127(3):213-222. https://doi.org/10.1111/j.1574-6968.1995. tb07476.x

Yazgan A, Ozcengiz G, Marahiel MA (2001) Tn10 insertional mutations of Bacillus subtilis that block the biosynthesis of bacilysin. Biochim Biophys Acta 1518:87-94

Young ME, Alakomi H, Fortune I, Gorbushina A, Krumbein W, Maxwell I, McCullagh C, Robertson P, Saarela M, Valero J, Vendrell M (2008) Development of a biocidal treatment regime to inhibit biological growths on cultural heritage: BIODAM. Environ Geol 56 (3):631-641

Zhao X, Kuipers O (2016) Identification and classification of known and putative antimicrobial compounds produced by a wide variety of Bacillales species. BMC Genomics 17(882):1-18

Open Access This chapter is licensed under the terms of the Creative Commons Attribution 4.0 International License (http://creativecommons.org/licenses/by/4.0/), which permits use, sharing, adaptation, distribution and reproduction in any medium or format, as long as you give appropriate credit to the original author(s) and the source, provide a link to the Creative Commons license and indicate if changes were made.

The images or other third party material in this chapter are included in the chapter's Creative Commons license, unless indicated otherwise in a credit line to the material. If material is not included in the chapter's Creative Commons license and your intended use is not permitted by statutory regulation or exceeds the permitted use, you will need to obtain permission directly from the copyright holder. 